\title{
Assessing water requirement of orange trees using sap flow measurements in Narkhed-Pandhurna critical zone observatory (CZO) in central India
}

\section{ASHUTOSH KUMAR MISHRA ${ }^{\mathrm{a}, \mathrm{b},}$ PARAS R. PUJARI ${ }^{\mathrm{a}, \mathrm{b},}$ SHALINI DHYANI ${ }^{\mathrm{a}}$,

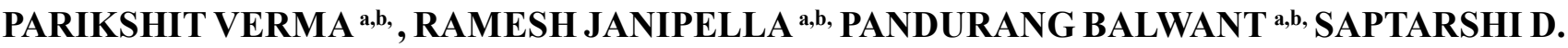 PURKAYASTHA ${ }^{\text {a }}$, RAFAT QUAMAR ${ }^{\mathrm{a}, \mathrm{b}}$, and JYOTHI VELIGETI ${ }^{\mathrm{a}}$}

\author{
${ }^{a}$ Water Technology \& Management Division, CSIR-National Environmental Engineering Research Institute, \\ Nagpur-440020, Maharashtra, INDIA \\ ${ }^{b}$ Academy of Scientific and Innovative Research, Ghaziabad-201 002, Uttar Pradesh, INDIA \\ *Corresponding author Email: p_verma@neeri.res.in,
}

\begin{abstract}
We used thermal dissipation method for sap flux measurements in orange trees to assess its water requirement in Narkhed-Pandhurna region. Thermal Dissipation Probe (TDP) sensors were installed in 5-year old (young) and 15-year old (mature) orange trees to measure the diurnal sap flux variations in trees during November 21, 2019, to January 31, 2020 (71 days). The results show that the maximum daily water uptake by the 5 -year old tree was $1.1 \mathrm{~L}$ observed on $39^{\text {th }}$ day of measurement (December 29, 2019) and in the 15-year old tree it was $5.0 \mathrm{~L}$, and it observed on $38^{\text {th }}$ day (December 28 , 2019) of measurement. The cumulative water uptake during the study period by the 5-year old tree was 49.0 L, and the 15-year old tree consumed $257.4 \mathrm{~L}$ of water. The results were compared with the recommended irrigational values of Indian Horticulture Board (IHB), Government of India (Gol) and Groundwater Survey and Development Agency (GSDA), Government of Maharashtra (GoMH) for orange orchards. The initial investigation shows that recommended guidelines for irrigation of orange trees are exorbitantly high and needs to be revised. The sap flow methods are more precise that can measure sap flow at a very short interval and can generate a time series of data. It can be used to revise the guidelines with the aim to conserve water and propose precision water irrigation for the study area in particular and different agro-climatic zones of the country in general.
\end{abstract}

Keywords: Orange tree, sap flow, thermal dissipation probe, water requirement

It is well established that land-atmospheric processes play a crucial role in regulating our climate (Sawyer et al., 2002; Seneviratne et al., 2008; Arneth et al., 2012; Guo \& Lin, 2016; Bonan, 2016). To bring more focus on these processes, and integrating studies that have been carried out by ecologist, hydrologist, geomorphologist, pedologist, geochemist, and climate scientist, the umbrella-term 'critical zone' was coined and defined by National Research Council, USA (NRC, 2001).Accordingly, the earth's critical zone is defined as the zone that lies between bedrock and tree canopy. The bio-geo-chemical processes in this zone are the result of the complex interaction between biotic and abiotic environment. The main research focus of $\mathrm{CZ}$ in the last few decades has been on understanding the interactions of these pertinent processes (Guo \& Lin, 2016 and Bonan, 2016) and the impact of land-use changes on vital ecosystem services provided by CZ (Banwart et al., 2011; Field et al., 2014; Guo \& Lin, 2016) for human well-being. Critical Zone Exploration Network (CZEN) currently has registered 59
CZOs worldwide, and two (2 nos) of them are in India (https://www.czen.org/).

The present study was carried out in NarkhedPandhurna (N-P) CZO, a small watershed (137 sq. km) in the semi-arid region located in the Nagpur (Maharashtra) and Chindwara (Madhya Pradesh) districts in central India (Fig 1). The watershed has up to sixth-order streams (ephemeral); Madar being the principal stream. The drainage pattern is dendritic. The study area is located at an elevation that ranges from $380 \mathrm{~m}$ amsl to $620 \mathrm{~m}$ amsl. Average annual temperature ranges from $12.2^{\circ} \mathrm{C}$ to $41.4^{\circ} \mathrm{C}$ (Climate data organisation, 2020) and average annual rainfall (20102019 ) is $837 \mathrm{~mm}$ (Department of Agriculture, Maharashtra, 2020). The study area has seven flows of Basalts overlying the Gondwanas (Krishnan, 1982). Soil in the study area is mainly characterised by black cotton soil and sandy-loam. More than $80.4 \%$ of the study area is intensively cultivated using varied agri-horticultural activities. Cotton, wheat, 


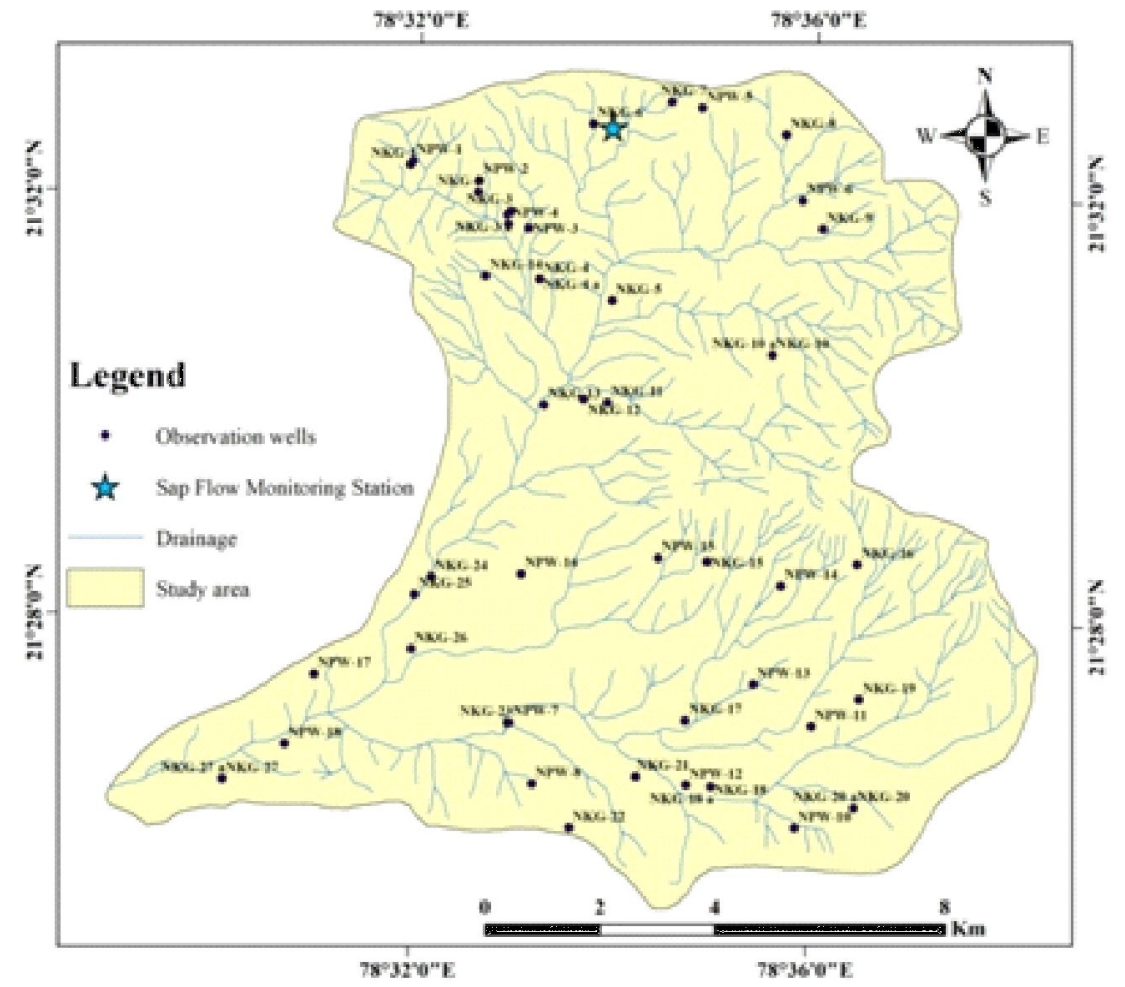

Fig. 1: Base map of the N-P CZO watershed

pigeon peas, and vegetables are important agriculture crop. The study area is known as the best orange producing belt in the Vidarbha region that gives Nagpur the name Orange city.

The orange cultivation is a water-intensive activity though, it and has been cultivated in the watershed from last five decades. The main reasons being favourable climatic conditions and economic viability. In the absence of any perennial surface water sources, groundwater is being extensively used for irrigation. At present, the calculated stage of groundwater development as per the Groundwater Resource Estimation Committee (GEC) 2015 guidelines is $100.14 \%$, and the study area falls in the over-exploited category. Frameworks for supporting groundwater protection and management in the country demands to assess the relationship of hydrology, plant species and its ecological processes (Aldous and Bach, 2014).

Many studies have been carried out to estimate the water requirement of crops; however, data for actual water required (transpiration) by trees is scarcely available (Poyatos et al., 2016). There are various methods available for the calculation of transpiration in a specific tree or on a regional scale (Sirgure et al., 2014 and Poyatos et al., 2016). Nowadays, thermometric methods are widely recommended due to its ability to make a precise measurement of sap flow
(Verma et al., 2014 and Poyatos et al., 2016; Waltham et al., 2017). In spite of the availability of these techniques, worldwide there are only 120 permanent sites where sap flow data is collected for about 160 species; however, India is missing in the database list (Poyatos et al., 2016).

In the absence of sap flow data for orange orchards, some recommendations have been proposed for the water requirement for trees (National Horticulture Board, 2020 and GSDA, 2015). However, these recommendations havenever been validated with sap flow data. The present study focuses on the measurement of sap flow in orange orchards in the N-P CZO water shed to verify the adequacy of the recommendations proposed by Indian Horticulture Board (IHB), Government of India (GoI) and Groundwater Survey and Development Agency (GSDA), Government of Maharashtra (GoMH). This is the very first attempt of sap flow measurements for the estimation of water requirement of orange trees in N-P CZO area in central India.

\section{MATERIALS AND METHODS}

The sap flux data were collected using Thermal Dissipation Probe (TDP) sensors (Dynamax Inc., USA) and the data was recorded using CR1000X measurement and control data logger, (Campbell Scientific, Inc., USA) (Fig. 2a). The meteorological data was collected throughan 

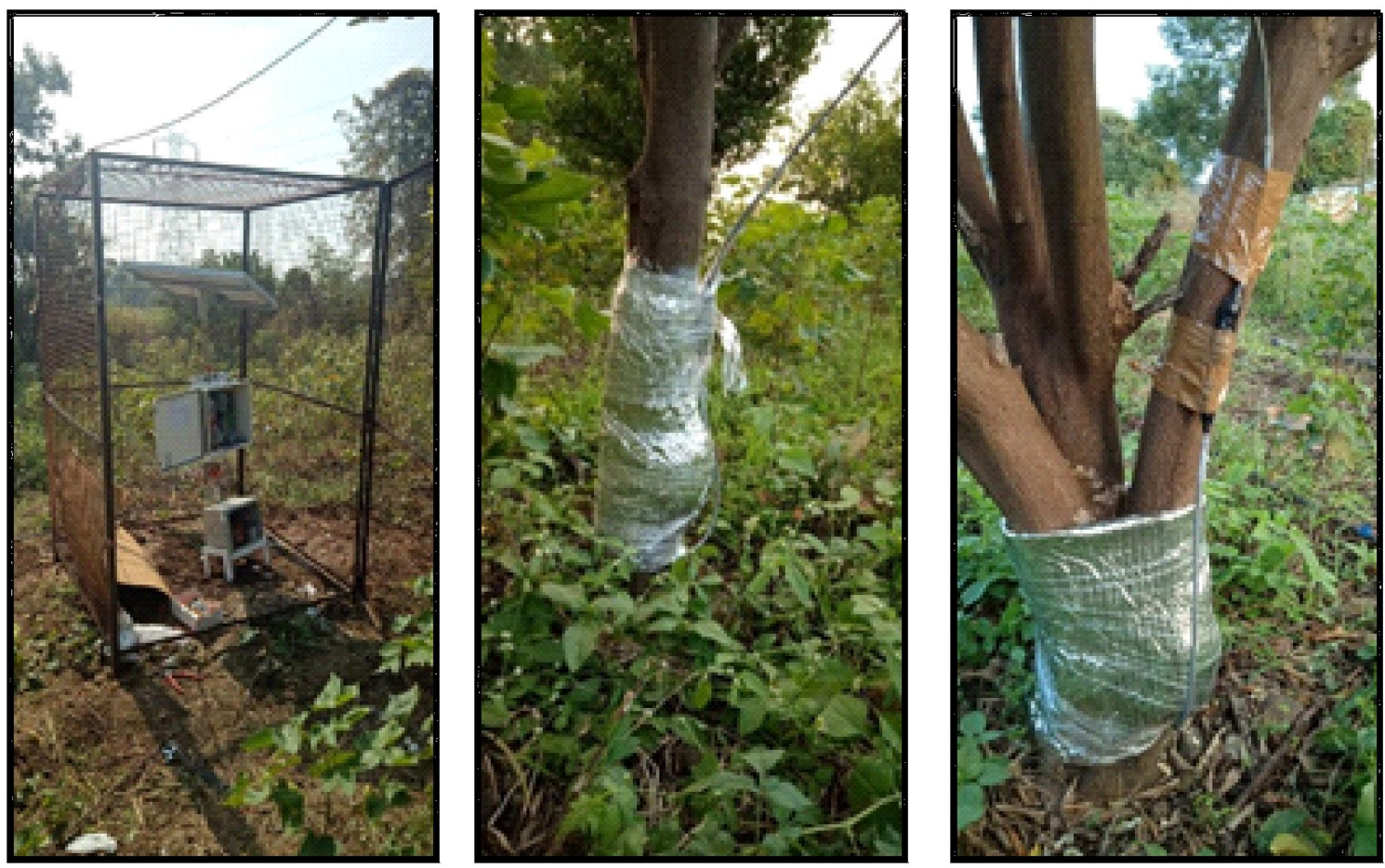

Fig. 2: (a) Continuous data logging system, (b) TDP sensor installed in a 5-year-old orange tree, (c) TDP sensor installed in a 15 -year-old orange tree

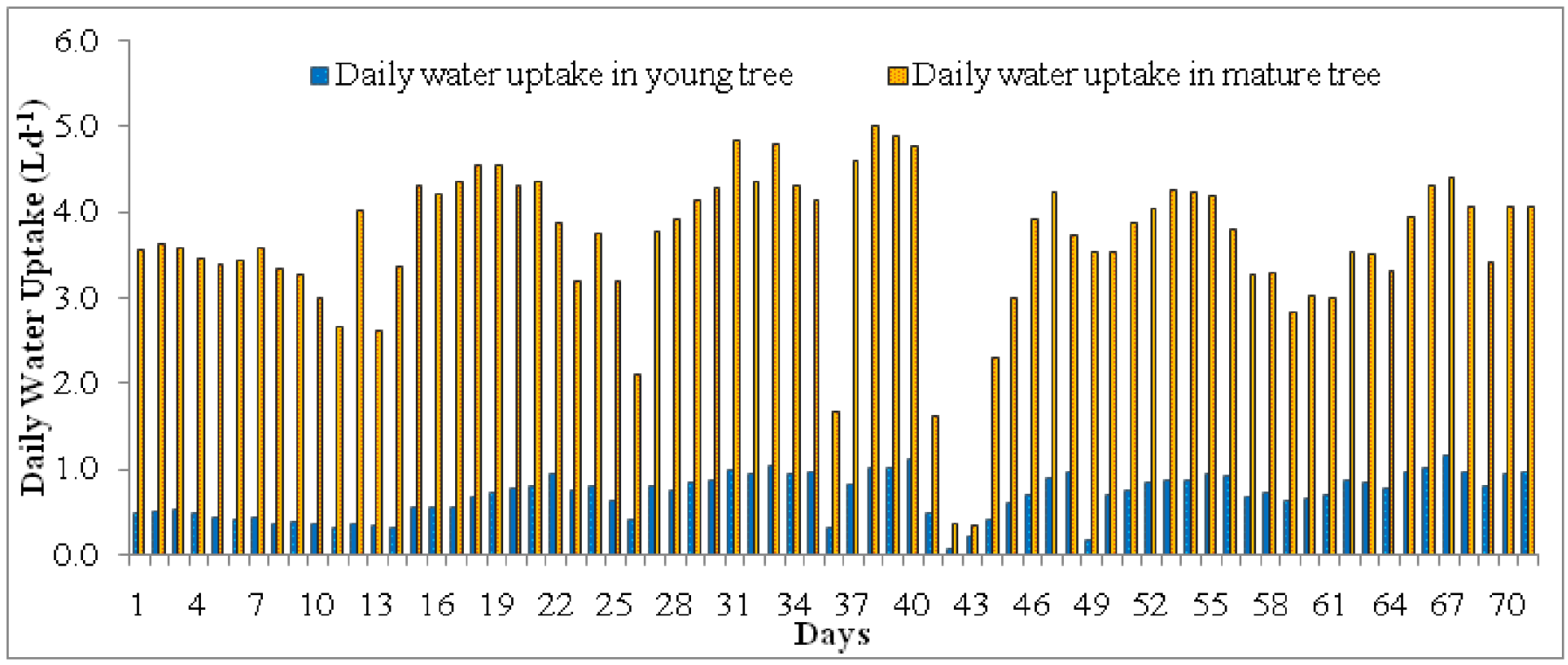

Fig. 3: Daily water uptake in a 5-year-old and 15-year old orange tree

automatic weather station (RainwiseInc. USA).The TDP sensors were installed in the main stem of the orange orchards just above $0.15 \mathrm{~m}$ from the ground (Fig. $2 \mathrm{~b}$ and $2 \mathrm{c}$ ). The meteorological parameters were collected by a weather station (Rainwise Inc., USA) installed near the orange orchard.

The sap flux data is collected at every 15 min interval in 5-year-old (young) tree and 15-year-old (matured) orchard trees. In the present study, we have reported data collected from November 21, 2019 to January 31, 2020 (71 days). The tree height and circumference of the stem (at $0.15 \mathrm{~m}$ ) of the 5 -year old tree were $2.7 \mathrm{~m}$ and $0.25 \mathrm{~m}$. The tree height and circumference of the stem (at $0.15 \mathrm{~m}$ ) of the 15 -year old tree were $3.4 \mathrm{~m}$ and $0.52 \mathrm{~m}$. 


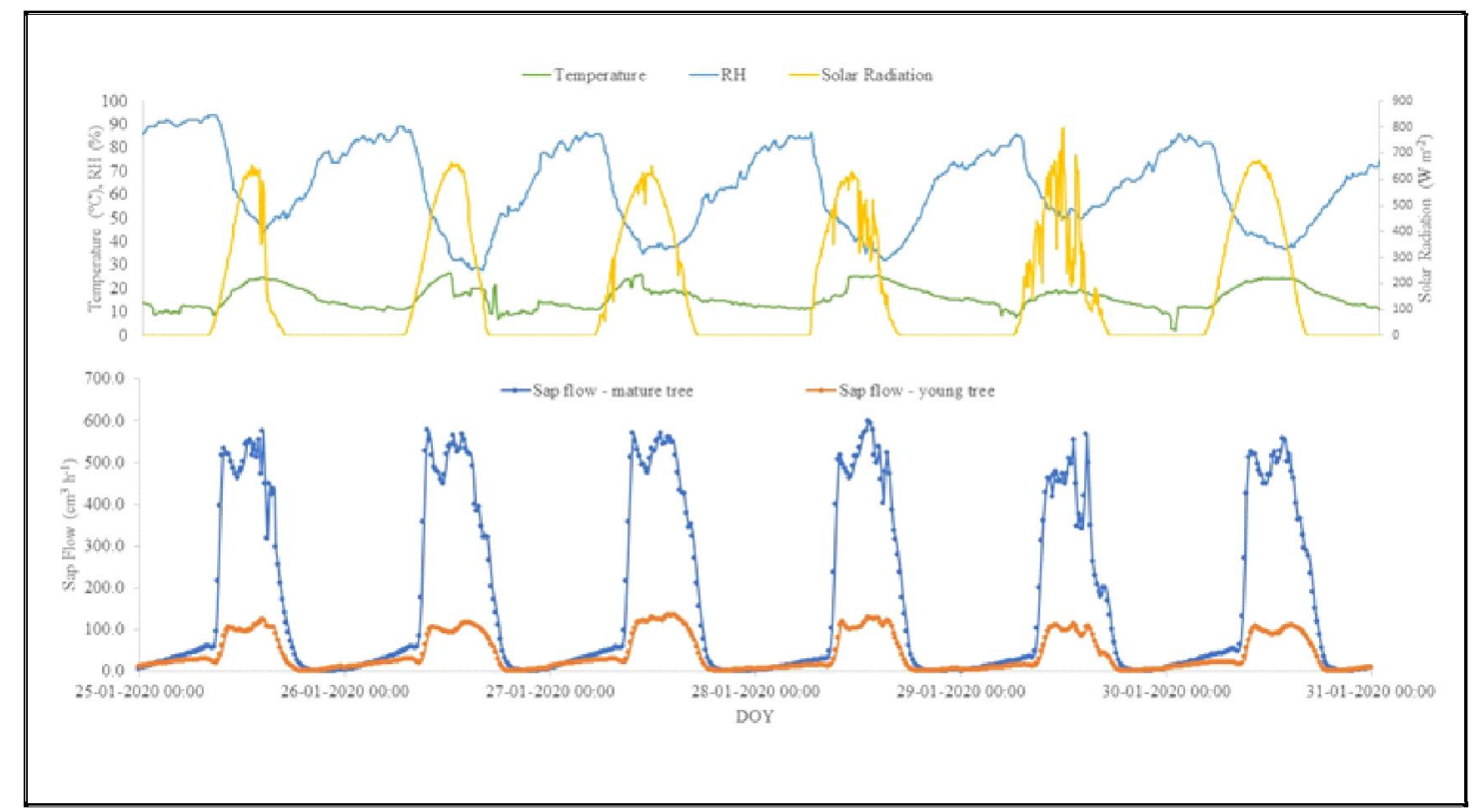

Fig. 4: Comparison of diurnal variation of sap flow in mature (15 years old) and young ( 05 -years old) Orange trees (bottom) with meteorological parameters (top)

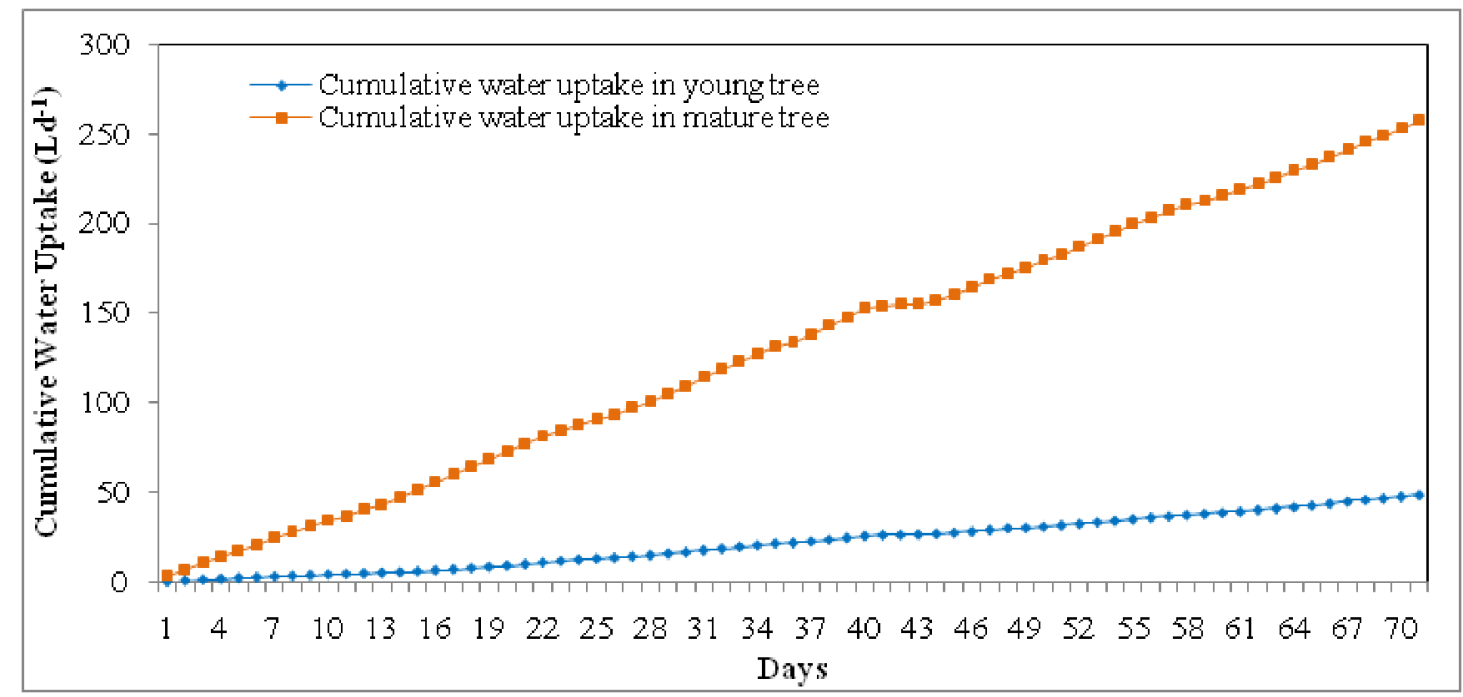

Fig. 5: Cumulative water uptake in a young and mature orange tree

The orange trees in the selected orchard are irrigated using groundwater through drip irrigation. The total numbers of orange trees in the selected orchard are 198 and a $7.5 \mathrm{HP}$ pump (Texmo Industries, UK) having a discharge of $3.2 \mathrm{lps}$ is used for withdrawing groundwater from bore well. The orange orchard during the winter season was irrigated for a period of $36 \mathrm{~h}$, and this cycle is repeated in every 15 days. Thus, on average, each tree receives $698 \mathrm{Ld}^{-1}$.

\section{RESULTS AND DISCUSSION}

\section{Sap flow and water uptake pattern}

Fig. 3 shows the daily and cumulative water uptake during November 21, 2019, to January 31, 2020 (71 days). The maximum daily water uptake by the 5 -year old tree was $1.1 \mathrm{~L}$ observed on $39^{\text {th }}$ day of measurement (December 29, 2019 ) and in the 15 -year old tree it was $5.0 \mathrm{~L}$, and it was observed on $38^{\text {th }}$ day (December 28, 2019) of measurement. The total water uptake by the 5-year old tree was $42.2 \mathrm{~L}$, and the 15 -year old tree consumed $229.2 \mathrm{~L}$ of water (Fig. 6). The total water consumed by the 15 -year old tree was significantly higher than the 5-year old tree.

\section{Comparison of sap flow with meteorological parameters}

The diurnal variation of sap flow in 5-year (young) 
Table 1: Comparison of calculated water uptake by each orange tree (Sap flow method) with the recommended water requirement of each tree during winter season (November-January)

\begin{tabular}{lllll}
\hline & $\begin{array}{l}\text { Calculated water } \\
\text { uptake (Sap flow } \\
\text { method) } \\
\left(\mathrm{Ld}^{-1}\right)\end{array}$ & $\begin{array}{l}\text { Present irrigation } \\
\text { (tree/day) } \\
\text { (Approx.) }\end{array}$ & $\begin{array}{l}\text { Water requirement } \\
\text { (tree/day) as per } \\
\text { NHB, GoI }\end{array}$ & $\begin{array}{l}\text { Water requirement } \\
\text { (tree/day) reported by } \\
\text { GSDA, GoMH }\end{array}$ \\
\hline 05 -Year-old (Young) tree & 0.65 & 698 & $5-15$ & $33-37$ \\
15 -Year-old (Mature) tree & 3.57 & 698 & $60-170$ & $52-57$ \\
\hline
\end{tabular}

and 15-year (matured) tree from January 25, 2020, to January 31, 2020, is presented in Fig. 4. It is observed that the peak sap flux in both the trees was during 09:00 am to 1:00 pm, during this period the solar radiation and ambient temperature also reaches its peak. However, the relative humidity observed to be minimum when the sap flow was highest. The maximum sap flow in the 15 -year-old tree was $599.0 \mathrm{~cm}^{3} \mathrm{~h}^{-1}$ and was observed on January 28, 2019, at 13:15 at the ambient temperature of $25^{\circ} \mathrm{C}$ with the relative humidity of $34 \%$ and solar radiation of $519 \mathrm{~W} \mathrm{~m}^{-2}$. The maximum sap flow in the 5 year-old (young) tree was $134.2 \mathrm{~cm}^{3} \mathrm{~h}^{-1}$ and was observed on January 27, 2020, at 14:00 at the ambient temperature of $19.5 \mathrm{C}$ with a relative humidity of $38 \%$ and solar radiation of $386 \mathrm{~W} \mathrm{~m}^{-2}$. The results show that the rate of sap flow in the orange tree is directly proposal to the ambient air temperature and solar radiation and inversely proposal to the relative humidity (Fig 4). This may be due to the increase in photosynthesis activity in the plant at a higher temperature and at a high solar intensity which increases the water demand in trees. The dryness in the air also accelerates the transpiration process and increases the rate of sap flow in the orange trees.

\section{Comparison of actual water uptake with recommended values}

In the case of orange orchards, the recommended water required for irrigation by NHB, GoI and GSDA, GoMHis presented in Table 1. Both NHB, GoI and GSDA, GoMH, suggest that for the 5 -year old tree the water required is between $5-37 \mathrm{Ld}^{-1}$ per tree and for the 15 -year old tree they recommend 52-170 $\mathrm{Ld}^{-1}$ per tree (Table 1). Similar estimates were given by Shirgure et al., (2014). The range suggested by them is wide and not precise, considering water scarcity in the region. Recently, more precise instruments like sap flow systems, are available that can measure sap flow at a very short interval and can generate time series of data (Cohen et al., 1991; Verma et al., 2014; Poyatos et al., 2016) that can be used to revise the guidelines with the aim to conserve waterand propose precision water irrigation for the study area in particular and different agro-climatic zones of the country in general.

The sap flow result of 5-year (young) and 15-year (mature) tree reveals that the recommended values of water for irrigation is exorbitantly high. In the winter season, the daily average sap flow in the 5 -year old tree was $0.64 \mathrm{Ld}^{-1}$, and in the 15 -year old tree, it was $3.57 \mathrm{Ld}^{-1}$. However, the recommended water requirement for the 5-year (young) and 15-year (mature) tree is 5-37 $\mathrm{Ld}^{-1}$ and $52-170 \mathrm{Ld}^{-}$ ${ }^{1}$ respectively.

Mahahoma (2016) presented the measurement of sap flow using heat ratio method (HRM) on citrus plants at a stand scale. The stand scale sap values reported by them are relatively small. The reason being difference in climatic conditions, tree density, tree phenology, soil type, and very low water application rate.

It is important to note here that the actual water that should be used for irrigation in the orange orchard should be significantly higher than the values reported in this article based on measurements of the sap flow. The reason being that we have to consider the losses due to evaporation and leakages to the vadose zone. Once, the estimate of these losses is added to these sap flow values, the actual water requirement can be obtained. However, these calculations are not straight forward as the water taken by the vegetation is a complex function of atmospheric conditions, plant phenology, and sub-surface properties. Complex mathematical models such as HYDRUS are available that take into account many of these processes and can be used to estimate precise water requirement under field conditions (Verma et al., 2014; Orellana et al., 2014; Aggarwal et al., 2017).

\section{CONCLUSION}

We used thermal dissipation method for sap flux measurements in the orange tree to assess its water 
requirement in Narkhed-Pandhurna region. Thermal Dissipation Probe (TDP) sensors were installed in 5-year old (young) and 15-year old (mature) orange trees to measure the diurnal sap flux variations in trees during November 21 , 2019 , to January 31,2020 ( 70 days). The results show that the maximum daily water uptake by the 5 -year old tree was $1.1 \mathrm{~L}$ observed on $39^{\text {th }}$ day of measurement (December 29, 2019) and in the 15-year old tree it was 5.0 L, and it observed on $38^{\text {th }}$ day (December 28,2019 ) of measurement. The total water uptake during the study period by the 5 -year old tree was $49.0 \mathrm{~L}$, and the 15 -year old tree consumed $257.4 \mathrm{~L}$ of water. The results were compared with the recommended irrigational values of Indian Horticulture Board (IHB), Government of India (GoI) and Groundwater Survey and Development Agency (GSDA), Government of Maharashtra (GoMH) for orange orchards. The initial investigation shows that recommended guidelines for irrigation of orange trees are exorbitantly high and needs to be revised. The sap flow methods are more precise that can measure sap flow at a very short interval and can generate a time series of data. It can be used to revise the guidelines with the aim to conserve water and propose precision water irrigation for the study area in particular and different agro-climatic zones of the country in general.

The TDP Sensors were used to measure the sap flux in young and mature orange trees. In order to assess the water requirement of trees. The temporal variation of sap flux was compared with the meteorological parameters to understand the effect of meteorological parameters on the water requirement of trees. Moreover, water uptake by tree were also compared with the actual

This study explores the role of advanced measurement techniques in computing precise water requirements for orange orchards. This measurement technique should be applied to obtain water requirement of different other species in different climatic zones as there is a significant data gap worldwide. This will require a more robust and comprehensive network for creating a database of sap flow for other species. This can help in addressing the growing groundwater woes, especially with reference to the water-energy-food nexus challenge..

\section{REFERENCE}

Aggarwal,P., Bhattacharyya, R., Mishra, A.K., Das, T.K., Šimunek, J., Pramanik, P., Sudhishri, S., Vashistha, A., Krishnan, P., Chakraborty, D., Kamble, K.H.(2017). Modelling soil water balance and root water uptake in cotton grown under different soil conservation practices in the IndoGangetic Plain. Agriculture, Ecosys. Environ., 240(1): 287-299.

Aldous, R.A, and Bach, L.B.(2014). Hydro-ecology of groundwater-dependent ecosystems: Applying basic science to groundwater management. Hydro. Sci. J., 2014,59(3-4)DOI: 10.1080/02626667.2014.889296.

Arneth, A., Mercado, L., Kattge, J., and Booth, B.B.B.(2012,) Future challenges of representing land-processes in studies on land-atmosphere interactions. Biogeosci., 9: 3587-3599.

Banwart, S., Bernasconi, S.M., Bloem, J., Blum, W., Brandao, M., Brantley, S., Chabaux, F., Duffy, C., Kram, P., Lair, G., Lundin, L., Nikolaidis, N., Novak, M., Panagos, P., Ragnarsdottir, K.V., Reynolds, B., Rousseva, S., de Ruiter, P., van Gaansn, P., van Riemsdijk, W., White, T., and Zhang B. (2011) Soil processes and functions in critical zone observatories: Hypotheses and experimental design. Vadose Zone J., 10:974-987. DOI:10.2136/ vzj2010.0136.

Bonan, G.B.(2016).Ecological Climatology: Concepts and Applications, Cambridge Univ. Press, ed. 3.

Cohen, Y.(1991). Determination of orchard water requirement by a combined trunk sap flow and meteorological approach. Irri. Sci., 12(2) :93-98.

Critical Zone Exploration Network (CZEN).https:// www.czen.org/site_seeker. (Accessed on March 25, 2019).

Database of climate data organisation.https://en.climatedata.org/asia/india/maharashtra/narkhed-968247/ (Accessed on April 04, 2020).

Database of Rainfall Recording and Analysis, Department of Agriculture Maharashtra State.http://maharain.gov.in/ (Accessed on April 04, 2020).

Field, J.P., Breshears, D.D., Law, D. J., Villegas J.C., LópezHoffman, L., Brooks P.D., Chorover, J, Barron-Gafford G.A., Gallery, R.E., Litvak, M.E., Lybrand R.A., McIntosh J.C., Meixner, T., Niu, G., Papuga, S.A., Pelletier, J.D., Rasmussen, C.R, Peter,A., andTroch, P.A.(2014).Critical Zone Services: Expanding Context, Constraints, and Currency beyond Ecosystem Services, Vadose Zone $J ., 14(1): 1-7$. doi:10.2136/vzj2014.10.0142.

Groundwater Surveys and Development Agency, Water Supply and Sanitation Department, Government of Maharashtra 
and Central Ground Water Board, Ministry of Jal Shakti, Government of India (2015). Aquifer maps and groundwater management plan: Katol and NarkhedTaluka, Nagpur District, Maharashtra (PartI).pp.24.http://cgwb.gov.in/AQM/NAQUIM_REPORT/ Maharshtra/Katol\%20 and \%20 Narkhed\% 20Taluka, \%20Nagpur\% 20District.pdf.

Guo, L., Lin, H. (2016). Critical Zone Research and Observatories: Current Status and Future Perspectives. Vadose Zone J., 15(9):2-14, DOI:010.2136/ vzj2016.06.0050.

Krishnan, M.S. (1982). Geology of India and Burma, CBS Publishers \& Distributors, $6^{\text {th }}$ Edition, 405-407 ISBN 10: 8123900120.

Mahahoma, W.,(2016) Measurment and modelingof water use of citrus orchards. (Doctoral Dessertation, University of Pretoria, South Africa).

National Horticulture Board, Government of India http:// nhb.gov.in/report_files/orange/ORANGE.htm\#: :text $=$ Water $\%$ 20requirement $\% 20$ of $\%$ 20citrus $\%$ 20trees, from $\% 20900 \% 20$ to $\% 201100 \% 20 \mathrm{~mm}$.

National Research Council (NRC), (2001).Basic research opportunities in the earth sciences.National Academies Press, Washington, DC, pp4.

Orellana F., Verma P., Loheide S.P., DalyE. (2012).Monitoring and modeling water vegetation interactions in groundwater dependent ecosystems. Reviews Geophy., $50(3)$.
Poyatos, R., Granda, V., Molowny-Horas, R., Mencuccini, M., Steppe, K., and Martínez-Vilalta, J. (2016).SAPFLUXNET: towards a global database of sap flow measurements. Tree Physiol., 36:1449-1455 DOI:10.1093/treephys/tpw110.

Sawyer, C, McCarty, P., and Parklin, G. (2002).Chemistry for Environmental Engineering. McGraw-Hill Education,

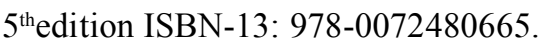

Seneviratne, S., and Stöckli, R.The Role of Land-Atmosphere Interactions for Climate Variability in Europe.In: Climate Variability and Extremes during the Past 100 Years(Brönnimann S., Luterbacher J., Ewen T., DiazH., Stolarski R.), pp 179-193.

Sirgure, P.S., Srivastava A.K., and Huchche, A.D. (2014).Water requirements in growth stages and effects of deficit irrigation on fruit productivity of drip-irrigated Nagpur mandarin (Citrus reticulata).Ind. J. Agri. Sci., 84 (3): $317-22$.

Verma, P., Steven, P., Loheide, S.P., Eamus, D., and Daly, E., (2014). Root water compensation sustains transpiration rates in an Australian woodland. Advances Water Res., 74: $91-10$.

Watham, T., Patel, N.R., Kushwaha, S.P.S., Dadhwal, V. K. (2017).A study on sap flow rate of Mallotusphilippensis and its relationship with environmental factors. $J$. Agrometeorol., 19(2):104-109. 